\title{
Polyethersulfone flat sheet and hollow fiber membranes from solutions in ionic liquids
}

DooLi Kim $^{\mathrm{a}}$, Hakkim Vovusha ${ }^{\mathrm{b}}$, Udo Schwingenschlögl ${ }^{\mathrm{b}}$, and Suzana P. Nunes ${ }^{\mathrm{a} *}$

${ }^{a}$ King Abdullah University of Science and Technology (KAUST), Biological and Environmental Science and Engineering Division (BESE), Thuwal, 23955-6900, Saudi Arabia

${ }^{\mathrm{b}}$ King Abdullah University of Science and Technology (KAUST), Physical Science and Engineering Division (PSE), Thuwal, 23955-6900, Saudi Arabia

Corresponding author: Prof. Suzana P. Nunes

Email: suzana.nunes@kaust.edu.sa 


\begin{abstract}
We fabricated flat-sheet and hollow fiber membranes from polyethersulfone (PES) solutions in two ionic liquids: 1-ethyl-3-methylimidazolium diethyl phosphate ([EMIM]DEP) and 1,3dimethylimidazolium dimethyl phosphate ([MMIM]DMP). The solvents are non-volatile and less toxic than organic solvents, such as dimethylformamide (DMF). The membranes morphologies were compared with those of membranes prepared from solutions in DMF, using electron microscopy. Water permeance, solute rejection and mechanical strengths were evaluated. Membranes were applied to DNA separation. While membranes based on PES were successfully prepared, polysulfone (PSf) does not dissolve in the same ionic liquids. The discrepancy between PES and PSf could not be explained using classical Flory-Huggins theory, which does not consider the coulombic contributions in ionic liquids. The differences in solubility could be understood, by applying density functional theory to estimate the interaction energy between the different polymers and solvents. The theoretical results were supported by experimental measurements of intrinsic viscosity and dynamic light scattering (DLS).
\end{abstract}

Keywords: polymer solution thermodynamics, polyethersulfone, [EMIM]DEP, [MMIM]DMP, hollow fibers, polymeric membranes, DNA separation, ionic liquids, density functional theory 


\section{INTRODUCTION}

Polyethersulfone (PES) is an excellent material for membrane fabrication with broad application for instance in desalination, biomedical devices and water treatment [1]. PES membranes have been playing an important role in purification of biotechnology product[2], such as typical proteins, peptides, and DNA, pharmaceutical products[3] , food[4], daily[5], and water[6, 7]. However, most of the PES membranes are fabricated from solvents, which are considered toxic, such as dimethylformaide (DMF), dimethylacetamide (DMAc), and Nmethyl-2 pyrrolidone (NMP), with potential environmental restrictions in the future [8]. Alternatives to replace these solvents are needed [9]. A few candidates are under consideration as greener solvents, such as supercritical fluids and ionic liquids $[10,11]$. We have focused on fabrication membranes using ionic liquids. Ionic liquids practically have no measurable vapor pressure and do not produce volatile organic compounds (VOCs), which normally contribute to health risks and negative environmental impact. Not all ionic liquids are considered green, but a number of them can be tuned and designed for sustainable processes $[10,12]$.

Many studies of cellulose dissolution in ionic liquid have been investigated [13-16]. The use of ionic liquids for membrane manufacture is still relatively restricted. Examples are: 1ethyl-3-methylimidazolium acetate [EMIM]OAc for polybenzimidazole [17], cellulose acetate (CA)[18], cellulose[19], and polyacrylonitrile[20]; 1-ethyl (or butyl)-3methylimidazolium thiocyanate ([EMIM]SCN and [BMIM]SCN) for CA[21, 22]. Recently we reported the fabrication of PES flat-sheet membranes using 1-ethyl-3-methylimidazolium diethylphosphate ([EMIM]DEP) [23]. Nano-size pore structures with high rejection of peptides were achieved.

Hollow fiber membranes are important for their large effective area, and high packing density in modules [24]. Manufacturing hollow fibers is more challenging than flat-sheet requiring a stricter viscosity control. Few studies on hollow fiber membrane fabrication based on ionic liquid polymer solutions have been reported. Xing, et al. [21] successfully spun hollow fiber membranes from the highly viscous polymer solution (approximately $100 \mathrm{~Pa}$.s at $1 \mathrm{1} / \mathrm{s}$ and $23{ }^{\circ} \mathrm{C}$ ) of $12 \mathrm{wt} \% \mathrm{CA}$ in [EMIM]SCN. Our group has fabricated hollow fiber membranes based on CA/[EMIM]OAc with/without cosolvent [18] and polyacrylonitrile 
(PAN)/[EMIM]OAc/co-solvent [20]. Here we first successfully fabricated hollow fiber membranes from highly viscous PES/[EMIM]DEP solutions and characterized them concerning the separation capacity of biotechnological product, and mechanical properties.

Second, we demonstrated the feasibility of another PES /ionic liquid system for membrane preparation. Finally, we use density functional theory to explain why PES solubility allows efficient membrane preparation, while polysulfone (PSf) with very similar chemical structure cannot be dissolved in the same solvents.

\section{METHODOLOGY}

\subsection{Materials}

Polyethersulfone (PES, average $\mathrm{Mw}=75,000$ provided from BASF) was purchased from BASF (Ultrason $®$ ). Polysulfone (PSf, average $\mathrm{Mw}=81,000$ ) was purchased from Solvey (Udel P-3500). 1-ethyl-3-methylimidazolium diethylphosphate ([EMIM]DEP, $\geq$ $98.0 \%)$, 1, 3-dimethyl- imidazolium dimethylphosphate ([MMIM]DMP), and dimethyl formamide (DMF, $\geq 99.8 \%$ ) were supplied by Sigma-Aldrich. Polymers and ionic liquids used in this study are illustrated in Figure 1. Polyethylene glycol (PEG) and/or polyethyleneoxide (PEO) (Sigma-Aldrich), with molecular weights $0.3,1.5,6,10$, and $35 \mathrm{~kg}$ $\mathrm{mol}^{-1}$, were applied for solute rejection evaluation and determination of the molecular weight cut-off (MWCO). Designed deoxyribonucleic acid (DNA, Sigma-Aldrich), with molecular weight of 3153 and $6366 \mathrm{~g} \mathrm{~mol}^{-1}$, was used for DNA rejection evaluation. 


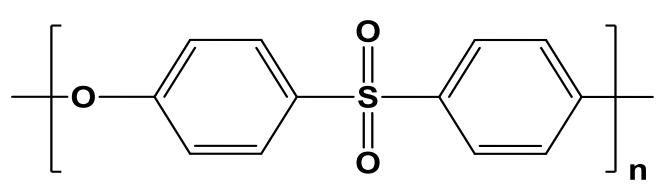

(a)

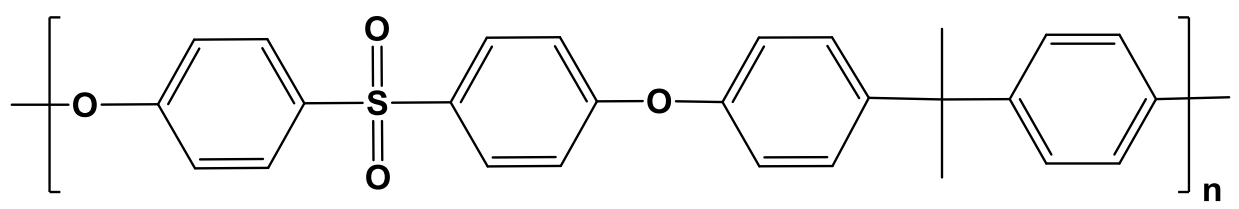

(b)

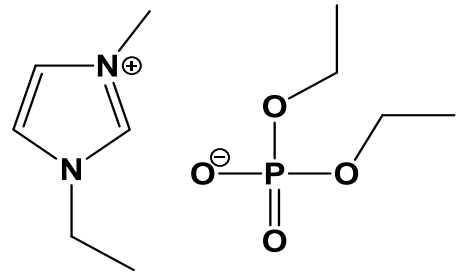

(c)

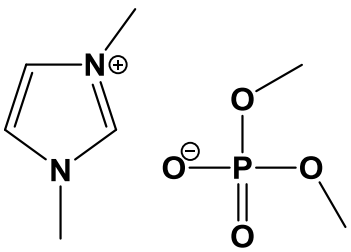

(d)

Figure 1. Chemical structures of (a) PES, (b) PSf, (c) [EMIM]DEP, and (d) [MMIM]DMP.

\subsection{Density functional theory (DFT) calculation}

All quantum chemical calculations employ the Gaussian 09 software package [25]. Structures are optimized with the M062X hybrid meta exchange-correlation functional [26] using a $6-31 \mathrm{G}^{*}$ basis set. The interaction energy between polymer and ionic liquid is calculated as:

$$
\mathrm{E}_{\text {int }}=\mathrm{E}_{\text {polymer+IL }}-\left(\mathrm{E}_{\text {polymer }}+\mathrm{E}_{\mathrm{IL}}\right)
$$

with $\mathrm{E}_{\text {polymer+IL }}, \mathrm{E}_{\text {polymer }}$, and $\mathrm{E}_{\mathrm{IL}}$ being the total energies of the combined system, polymer, and ionic liquid, respectively. Electrostatic, dispersion, induction, and exchange contributions to $E_{\text {int }}=E_{\text {elec }}+E_{\text {dispersion }}+E_{\text {induction }}+E_{\text {exchange }}$ are determined by symmetry adopted perturbation theory using the Psi4 program [27].

\subsection{Experimental polymer solution characterization}

Binary systems (polymer/solvent) 
Parallel to the computational estimation, experimental measurements of the polymer coil size were provided by intrinsic viscosity $([\eta])$, dynamic light scattering (DLS, Zetasizer, Malvern). To measure the intrinsic viscosity, different PES solutions (0.05; 0.1 ; and $0.2 \mathrm{wt} \%$ ) were prepared in [EMIM]DEP, [MMIM]DMP, and DMF and the viscosity was with a Ubbelohde viscometer (Lauda iVisc) at $25^{\circ} \mathrm{C}$. From the viscosity of the series of diluted polymer solutions, the intrinsic viscosity was calculated using the following equation 3 :

$$
[\eta]=\lim _{\mathrm{c} \rightarrow \mathrm{o}}\left(\frac{\eta_{\text {rel }}-1}{\mathrm{c}}\right)=\lim _{\mathrm{c} \rightarrow \mathrm{o}} \eta_{\text {red }}
$$

where, $\eta_{\text {rel }}$ is the relative viscosity (defined as $\eta_{\text {rel }}=$ polymer solution dynamic viscosity $/$ solvent dynamic viscosity), $\eta_{\text {red }}$ is the reduced viscosity (defined as $\eta_{\text {red }}=\left(\eta_{\text {rel }}-1\right) / C$ ), and C is the concentration of the polymer solution. From the intrinsic viscosity, the coil size was calculated by the following equation 4 and 5 [28]:

$$
\begin{aligned}
& C^{*}=\frac{1}{\eta} \\
& C^{*}=\frac{M}{\frac{4}{3} \pi N_{A} R_{g}^{3}}
\end{aligned}
$$

where, $C^{*}$ is the concentration which the polymer coils start to entangle. [ $\left.\eta\right]$ is the intrinsic viscosity $\left(\mathrm{cm}^{3} / \mathrm{g}\right), M$ is the polymer molecular weight $\left(\mathrm{g} \mathrm{mol}^{-1}\right), N_{A}$ is the Avogadro number $\left(6.022 \times 10^{23} \mathrm{~mol}^{-1}\right), R_{g}$ is the radius of gyration $(\mathrm{cm})$, respectively. From the intrinsic viscosity in equation $4, \mathrm{C}^{*}$ and the radius of gyration $R_{g}$, the hydrodynamic radius $R_{h}$ and the diameter $D_{h}\left(D_{h}=2 * R_{h}\right)$ can be calculated.

For DLS, 0.1 wt\% PES solutions in [EMIM]DEP, [MMIM]DMP, and DMF were prepared and filtered through membranes with $0.2 \mu \mathrm{m}$ pores before analysis. The experiments were done using He-Ne laser with wavelength $633 \mathrm{~nm}$.

\section{Ternary systems (polymer/solvent/non-solvent)}

The phase diagram was estimated by measuring cloud points starting with binary polymer/solvent solutions and adding water. The PES solutions with various concentrations were prepared in different solvents. The detected turbid points (the cloud points) determine 
the binodal curve for a specific PES/solvent/water system. The binodal denotes the boundary between the stable (one phase) region and the meta-stable region of the phase diagram.

Viscosity is an important kinetic factor to understand effects of solvent and nonsolvent diffusion rate during the membrane formation and for practical reasons and limitations of membrane fabrication especially for hollow fiber membranes, appropriate viscosity is essential for the hollow fiber spinning process. The viscosity of polymer solutions was evaluated in an AR1500ex Rheometer (TA Instruments) at different temperatures at $10 \mathrm{~s}^{-}$ ${ }^{1}$ shear rate. In this work, a polymer concentration of $12 \mathrm{wt} \%$ was applied for spinning hollow fibers in different temperatures.

\subsection{Membrane preparation}

For flat sheet membrane fabrication, four different polymer solutions, $12 \mathrm{wt} \%$ of PES in [EMIM]DEP; [MMIM]DMP; DMF; and $18 \mathrm{wt} \%$ of PES in DMF, were prepared. $12 \mathrm{wt} \%$ of PES was dissolved in the ionic liquids at $90{ }^{\circ} \mathrm{C}$ and stirred for a day. In the case of the PES solution in DMF, PES was dissolved at $60{ }^{\circ} \mathrm{C}$, stirring for a day. Polymer solutions were cast on a glass plate with a doctor blade with $250 \mu \mathrm{m}$ gap at room temperature and then immediately immersed into deionized water as non-solvent to induce the phase inversion.

For hollow fiber membranes, 12 wt \% PES in [EMIM]DEP and 18 wt\% PES in DMF were used as dope solutions with appropriate range of viscosity. The polymer solutions were poured into the dope reservoir and degassed for two day at $70{ }^{\circ} \mathrm{C}$ under the pressure of 2 bars. The polymer solutions were spun with the spinning conditions listed in Table 1 using a spinneret (inner: outer diameter $=0.34 \mathrm{~mm}$ : $0.61 \mathrm{~mm}$ ). The spun fibers were immersed in deionized water for a day to remove residual solvents, then immersed in glycerol solution (glycerol: 2-propanol = 50: 50) for 2 hours to avoid pore collapse, and dried in atmosphere. 
Table 1. Spinning conditions for hollow fiber membranes

\begin{tabular}{|c|c|c|c|c|c|}
\hline $\begin{array}{c}\text { Sample code } \\
\text { (Solutions in ionic liquids) }\end{array}$ & $\begin{array}{c}\text { 18PES/ } \\
\text { DMF-2/25 }\end{array}$ & $\begin{array}{l}\text { 12PES/ } \\
\text { IL-2/70 }\end{array}$ & $\begin{array}{l}\text { 12PES/ } \\
\text { IL-5/70 }\end{array}$ & $\begin{array}{l}\text { 12PES/ } \\
\text { IL-5/90 }\end{array}$ & $\begin{array}{l}\text { 12PES/ } \\
\text { IL-30/90 }\end{array}$ \\
\hline Dope solution composition (wt\%) & $\begin{array}{l}18 \mathrm{wt} \% \\
\mathrm{PES} / \mathrm{DMF}\end{array}$ & \multicolumn{4}{|c|}{$12 \mathrm{wt} \% \mathrm{PES} /[\mathrm{EMIM}] \mathrm{DEP}$} \\
\hline Composition of bore fluid (wt\%) & \multicolumn{5}{|c|}{ Water } \\
\hline Coagulant bath & \multicolumn{5}{|c|}{ Water } \\
\hline Air gap (cm) & \multirow[t]{3}{*}{2} & \multirow[t]{3}{*}{2} & 5 & \multirow[t]{3}{*}{5} & \multirow[t]{3}{*}{30} \\
\hline $\begin{array}{l}\text { Flow rate of dope solution } \\
(\mathrm{ml} / \mathrm{min})\end{array}$ & & & 5 & & \\
\hline $\begin{array}{l}\text { Flow rate of inner coagulant } \\
(\mathrm{ml} / \mathrm{min})\end{array}$ & & & 3 & & \\
\hline Take up speed (m/min) & \multicolumn{5}{|c|}{ Free fall } \\
\hline $\begin{array}{l}\text { Temperature of the dope solutions } \\
\left({ }^{\circ} \mathrm{C}\right)\end{array}$ & 25 & 70 & 70 & 90 & \multirow[t]{2}{*}{90} \\
\hline $\begin{array}{l}\text { Temperature of the bore fluid and } \\
\text { the coagulant bath }\left({ }^{\circ} \mathrm{C}\right)\end{array}$ & & & 25 & & \\
\hline
\end{tabular}




\subsection{Membrane characterizations}

The membrane morphology was observed on FEI Quanta 200, 600, and Nova Nano Field Emission Scanning Electron Microscopes (FESEM). For the cross-section images, the pretreated membranes, soaked in glycerol solution (glycerol: 2-propanol $=50: 50$ ) and dried in atmosphere to avoid pore collapse, were fractured in liquid nitrogen and then sputter coated with iridium.

Pure water permeance was measured under 2 bar in a dead-end filtration cell with the stirring speed of $400 \mathrm{rpm}$, calculated with the following equation:

$$
\text { Pure water permeance }\left(L m^{-2} h^{-1} \text { bar }^{-1}\right)=Q \cdot A^{-1} \cdot \Delta P^{-1}
$$

where $Q$ is the permeated pure water rate $\left(\mathrm{L} \mathrm{h}^{-1}\right), A$ is the effective membrane area $\left(\mathrm{m}^{2}\right)$, and $\Delta P$ is the pressure (bar).

For measuring the PEGs rejection, mixed and single PEG solutions were prepared. In the case of the mixed feed solution, the $0.1 \mathrm{wt} \%$ PEGs with the molecular weight of $6 ; 10 ; 35$; and $100 \mathrm{~kg} \mathrm{~mol}^{-1}$, were mixed together in water. For the single PEG feed solutions, the $0.1 \mathrm{wt} \%$ PEGs of $1.5 ; 3$; and $6 \mathrm{~kg} \mathrm{~mol}^{-1}$ were prepared in water separately. Using the PEG feed solutions, all membranes were tested in a dead-end cell with stirring speed of $400 \mathrm{rpm}$ under 2 bar. The PEG concentration of the feed and permeated solution was analyzed by Gel Permeation Chromatography (GPC) with PL aquagel-OH 40 and 60 columns, (1260 infinity GPC/SEC, Agilent technologies). The PEG rejection were calculated by the equation 7:

$$
\text { PEG rejection, } R(\%)=\left(1-\frac{C_{\text {perm }}}{C_{\text {feed }}}\right) \times 100 \%
$$

where $C_{\text {perm }}$ and $C_{\text {feed }}$ are the concentrations of the permeate and feed solutions, respectively.

Based on the results of the PEG rejection, pore size, pore distribution, and MWCO of all membranes were calculated. The solute (PEG and PEO) diameter was calculated using the Stokes radius equation $[29,30]$ :

\section{For PEG}

$$
r=16.73 \times 10^{-10} M^{0.557}
$$

For PEO

$$
r=10.44 \times 10^{-10} M^{0.587}
$$


where $r$ is the Stokes radius (in $\mathrm{cm}$ ) and $M$ is the molecular weight of PEG and PEO $\left(\mathrm{g} \mathrm{mol}^{-1}\right)$. The rejections were plotted as a function of the Stokes diameters $(d=2 r)$ corresponding to each molecular weight and their relations are shown the equation 10 and the pore size probability of membranes is expressed by the equation 11 .

$$
\begin{aligned}
& F(R)=A+B(\ln d) \\
& \frac{\partial R\left(d_{p}\right)}{\partial d_{p}}=\frac{1}{d_{p} \ln _{p} \sqrt{2}} \exp \left[\frac{\left(\ln d_{p} \ln { }_{p}\right)^{2}}{2\left(\ln { }_{p}\right)^{2}}\right]
\end{aligned}
$$

where $\mu_{p}$ is the mean effective pore size diameter at $R=50 \%$ and $\sigma_{p}$ is the geometric standard deviation, defined as the ratio of $d$ values at $R=84.13$ and $50 \%$ by neglecting the steric and hydrodynamic hindrance effects [31] and ignoring the deformation of macromolecules under pressure and shear rate in the solution [32]. From the plot of the equation 10, the mean pore size $\left(d_{s}\right)$ and the molecular weight cut-off (MWCO, the molecular weight corresponding to $90 \%$ rejection) were determined at $R=90 \%$.

\subsection{DNA separation}

The capacity of DNA separation of all flat sheet membranes was examined. The DNA samples were designed with molecular weight 3153 and $6366 \mathrm{~g} \mathrm{~mol}^{-1}$, and dissolved in deionized water. The solutions were filtered in a dead-end ultrafiltration set-up (Amicon cell). The permeate and feed solutions were collected to calculate the rejection. The concentration of the collected solutions was analyzed by a UV spectrometer at $260 \mathrm{~nm}$ (Thermo scientific, Nanodrop 2000c). The rejection was calculated by equation 5 .

\subsection{Mechanical properties}

The mechanical properties of flat sheet and hollow fiber membranes, such as tensile strength and elongation at break, were measured by dynamic mechanical analysis (Q800, TA instrument) at room temperature with the force rate of $0.05 \mathrm{~N} / \mathrm{min}$. 


\section{RESULTS}

The solubility of PES and PSf in [EMIM]DEP, [MMIM]DMP, and DMF was tested, by adding $1 \mathrm{wt} \%$ polymer to each solvent. PES completely dissolved in all solvents. PSf was not soluble in the ionic liquids, but dissolved in DMF. As shown in Figure 1, the main difference in chemical structure between PES and PSf is that the repeating unit of PSf contains diphenyl dimethyl groups. Two methyl and two phenyl groups in PSf monomer may affect on the total energy (or electron) distribution and result in not being miscible with ionic liquids, which have strong hydrogen bonds and Coulombic forces.

\subsection{Density functional theory (DFT) calculation}

To explain why PES but not PSf dissolves in [EMIM]DEP and [MMIM]DMP, the interaction energy of PES and PSf with the ionic liquids is calculated by density functional theory for monomers (PES1 and PSf1) and dimers (PES2 and PSf2). The ionic liquids are placed at different sites of PES and PSf to identify, by means of relaxation, the lowest energy structures (illustrated for monomers in Figure 2), which then are used for further analysis. For the monomers, the interaction energy turns out to be $-13.1 \mathrm{kcal} \mathrm{mol}^{-1}$ for PES1/[EMIM]DEP and $-5.4 \mathrm{kcal} \mathrm{mol}^{-1}$ for PSf1/[EMIM]DEP, while for the dimers it is -13.1 $\mathrm{kcal} \mathrm{mol}^{-1}$ for PES2/[EMIM]DEP and $-7.9 \mathrm{kcal} \mathrm{mol}^{-1}$ for PSf2/[EMIM]DEP. More negative values for PES than for PSf can explain why PES is soluble in the ionic liquids in contrast to PSf. Equivalent results are found for [MMIM]DMP, with the interaction energy for the PES monomer and dimer amounting to -15.5 and $-20.8 \mathrm{kcal} \mathrm{mol}^{-1}$, respectively, and that for the PSf monomer and dimer to -8.3 and $-6.9 \mathrm{kcal} \mathrm{mol}^{-1}$. To understand the nature of the interaction, the energy contributions are decomposed in each case, see the results given in Table 2. The electrostatic energy always exceeds the dispersion and induction energies. Only for PES1/[EMIM]DEP and PES1/[MMIM]DMP the induction energy is larger than the dispersion energy. 

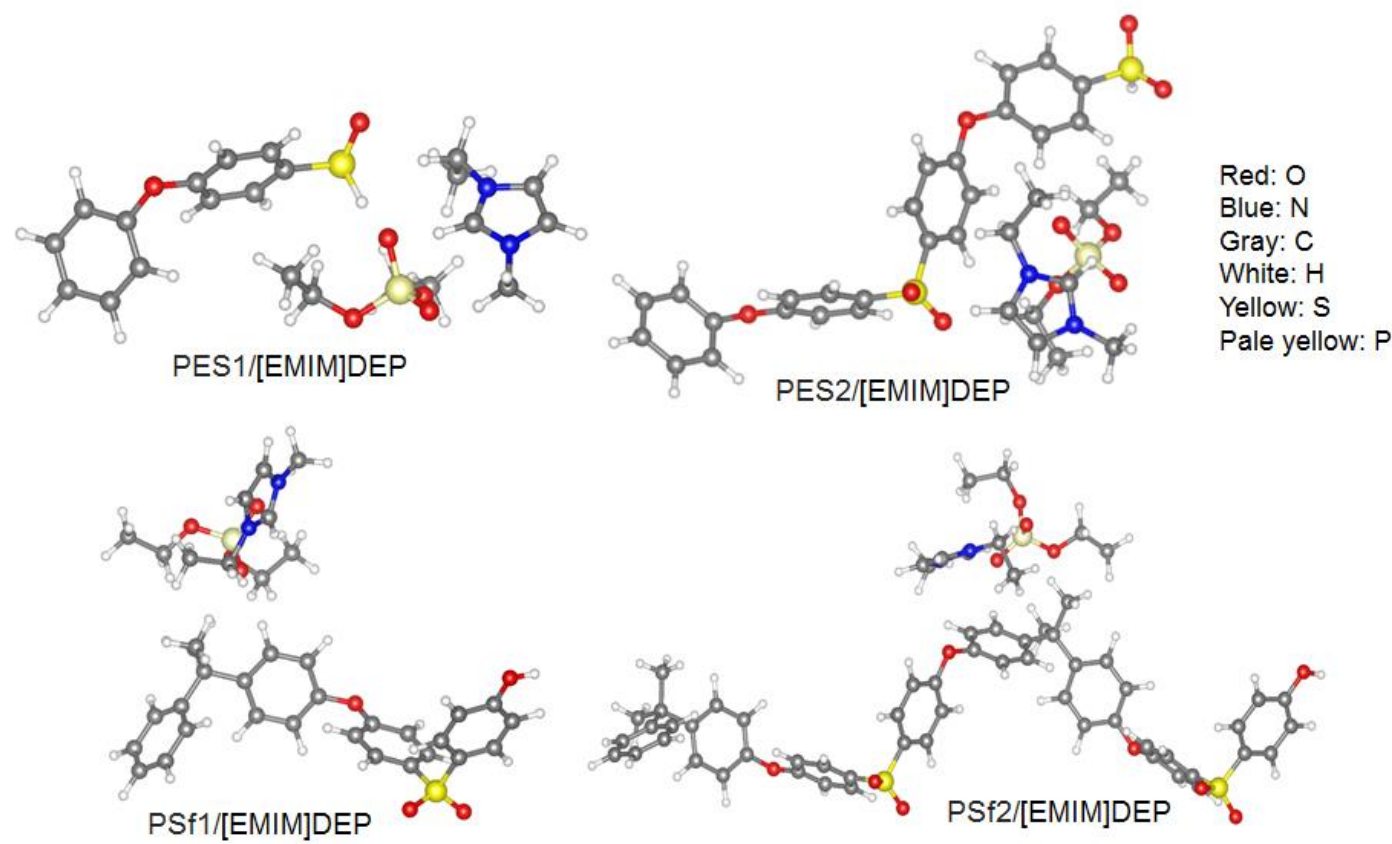

(a)

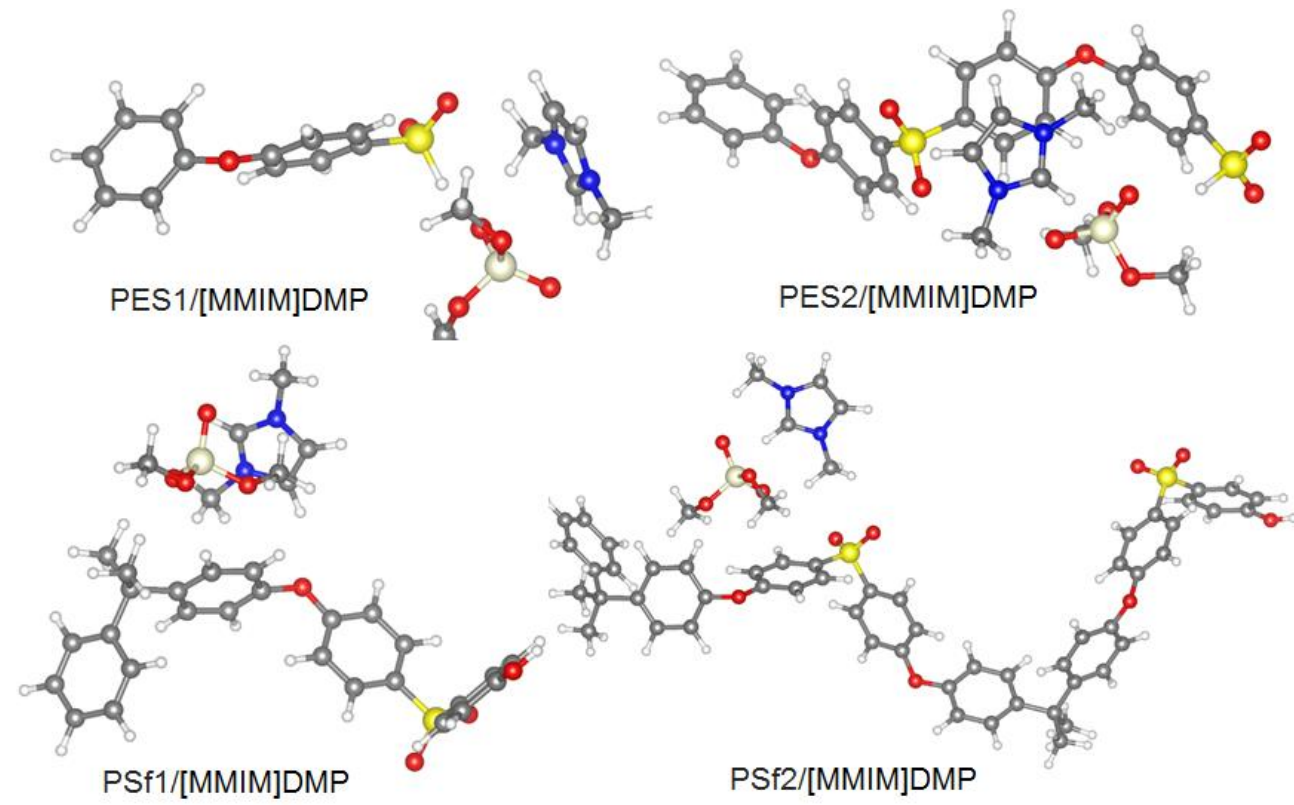

(b)

Figure 2. Lowest energy structures of monomers (PES1 and PSf1) and dimers (PES2 and PSf2) surrounded by ionic liquid cations and anions: (a) $[\mathrm{EMIM}]^{+}$and $\mathrm{DEP}^{-}$and (b) $\left[\mathrm{MMIM}^{+}\right.$and $\mathrm{DMP}^{-}$. 
Table 2. Energy decomposition analysis.

\begin{tabular}{lc|cccc}
\hline \multirow{2}{*}{ Polymer/ Ionic liquid } & \multicolumn{5}{c}{ Energy $\left(\mathrm{kcal} \mathrm{\textrm {mol } ^ { - 1 } )}\right.$} \\
\cline { 2 - 6 } & $\mathrm{E}_{\text {int }}$ & $\mathrm{E}_{\text {elec }}$ & $\mathrm{E}_{\text {dispersion }}$ & $\mathrm{E}_{\text {induction }}$ & $\mathrm{E}_{\text {exchange }}$ \\
\hline PES1/[EMIM]DEP & -13.1 & -33.6 & -11.9 & -16.4 & 46.9 \\
PES2/[EMIM]DEP & -13.1 & -24.3 & -16.1 & -7.9 & 34.2 \\
PSf1/[EMIM]DEP & -5.4 & -11.5 & -8.2 & -4.3 & 17.9 \\
PSf2/[EMIM]DEP & -7.3 & -14.9 & -14.4 & -5.4 & 26.4 \\
\hline PES1/[MMIM]DMP & -15.5 & -36.8 & -9.6 & -18.0 & 46.1 \\
PES2/[MMIM]DMP & -20.8 & -37.7 & -20.0 & -10.8 & 46.5 \\
PSf1/[MMIM]DMP & -8.3 & -17.0 & -12.6 & -6.5 & 26.8 \\
PSf2/[MMIM]DMP & -6.9 & -16.9 & -12.2 & -4.8 & 26.1 \\
\hline
\end{tabular}

\subsection{Polymer solutions characterization}

Diluted polymer solution (polymer/solvent binary systems)

In the cases of homogenous polymer solutions, large polymer coils indicate a strong polymer solvent interaction, leading to high thermodynamic stability. The size (hydrodynamic diameter) of PES coils in diluted solutions with different solvents was estimated by DLS and intrinsic viscosity (Table 3). The hydrodynamic diameter of diluted PES in [MMIM]DMP was the largest among all systems, independently of the measurement method. The order of the hydrodynamic diameter was PES/[MMIM]DMP $\geq$ $\mathrm{PES} /[\mathrm{EMIM}] \mathrm{DEP} \geq \mathrm{PES} / \mathrm{DMF}$. PES/[MMIM]DMP seems to have a stronger interaction than PES/[EMIM]DEP, which is consistent with the results of DFT calculation. It can be interpreted that the ionic liquids, [MMIM]DMP and [EMIM]DEP, are good solvents for PES, better than DMF. 
Table 3. Intrinsic viscosity $([\eta])$, entanglement concentration $\left(C^{*}\right)$, radius of gyration $\left(R_{\mathrm{g}}\right)$, hydrodynamic diameter obtained from the intrinsic viscosity $\left(\mathrm{D}_{\mathrm{h}([\eta]-1)}\right)$ and DLS $\left(\mathrm{D}_{\mathrm{h}}(\mathrm{DLS})\right.$ ), and solvent density.

\begin{tabular}{|c|c|c|c|c|c|c|c|c|}
\hline \multirow[t]{2}{*}{ PES/solvents } & \multicolumn{2}{|c|}{$\begin{array}{c}\text { Intrinsic } \\
\text { viscosity }(\eta) \\
\left(\mathrm{cm}^{3} / \mathrm{g}\right) \\
\end{array}$} & \multirow{2}{*}{$\begin{array}{c}\mathrm{C}^{*} \\
([\mathrm{\eta}]-1) \\
\left(\mathrm{g} / \mathrm{cm}^{3}\right)\end{array}$} & \multirow[t]{2}{*}{$\begin{array}{c}\mathrm{R}_{\mathrm{g}} \\
([\eta]-1) \\
(\mathrm{nm})\end{array}$} & \multirow[t]{2}{*}{$\begin{array}{c}\mathrm{R}_{\mathrm{h}} \\
([\eta]-1) \\
(\mathrm{nm})\end{array}$} & \multirow{2}{*}{$\begin{array}{c}\mathrm{D}_{\mathrm{h}} \\
([\eta]-1) \\
(\mathrm{nm})\end{array}$} & \multirow[t]{2}{*}{$\begin{array}{l}\mathrm{D}_{\mathrm{h}}{ }^{\mathrm{c}} \\
(\mathrm{DLS}) \\
(\mathrm{nm})\end{array}$} & \multirow[t]{2}{*}{$\begin{array}{l}\text { Solvent } \\
\text { density } \\
\left(\mathrm{g} / \mathrm{cm}^{3}\right)\end{array}$} \\
\hline & Exp. $^{a}$ & Ref. & & & & & & \\
\hline [EMIM]DEP & 58.5 & - & 0.017 & 12.0 & 15.6 & 31.2 & 15.1 & 1.1458 \\
\hline [MMIM]DMP & 96.4 & - & 0.010 & 14.2 & 18.5 & 36.9 & 18.2 & 1.2532 \\
\hline $\mathrm{DMF}$ & 52.0 & $\begin{array}{c}41.6^{\mathrm{b}} \\
{[33]}\end{array}$ & 0.019 & 11.6 & 15.0 & 30.0 & 13.1 & 0.9474 \\
\hline
\end{tabular}

${ }^{\mathrm{a}}$ Measured for PES $\left(\mathrm{Mw}=75 \mathrm{~kg} \mathrm{~mol}^{-1}\right)$ at $25^{\circ} \mathrm{C}$

${ }^{\mathrm{b}}$ Measured for PES $\left(\mathrm{Mw}=70 \mathrm{~kg} \mathrm{~mol}^{-1}\right)$ at $23{ }^{\circ} \mathrm{C} ;[\eta]=63.3 \mathrm{~cm}^{3} / \mathrm{g}$ for $\mathrm{Mw}=113 \mathrm{~kg} \mathrm{~mol}^{-1}$.

${ }^{\mathrm{c}}$ Measured by DLS $\left(\mathrm{D}_{\mathrm{h}(\mathrm{DLS})}\right)$ at $25^{\circ} \mathrm{C}$

${ }^{\mathrm{d}}$ Measured with a pycnometer at $22 \pm 1^{\circ} \mathrm{C}$.

Phase diagram (ternary system, polymer/solvents/water)

Figure 3 shows the phase diagrams for different PES/solvent/water systems, obtained by cloud point measurements. The phase diagrams are similar. Minor differences were observed, with the two-phases regions increasing in the following order: $\mathrm{PES} /[\mathrm{MMIM}] \mathrm{DMP} \approx \mathrm{PES} /[\mathrm{EMIM}] \mathrm{DEP} \leq \mathrm{PES} / \mathrm{DMF}$. 


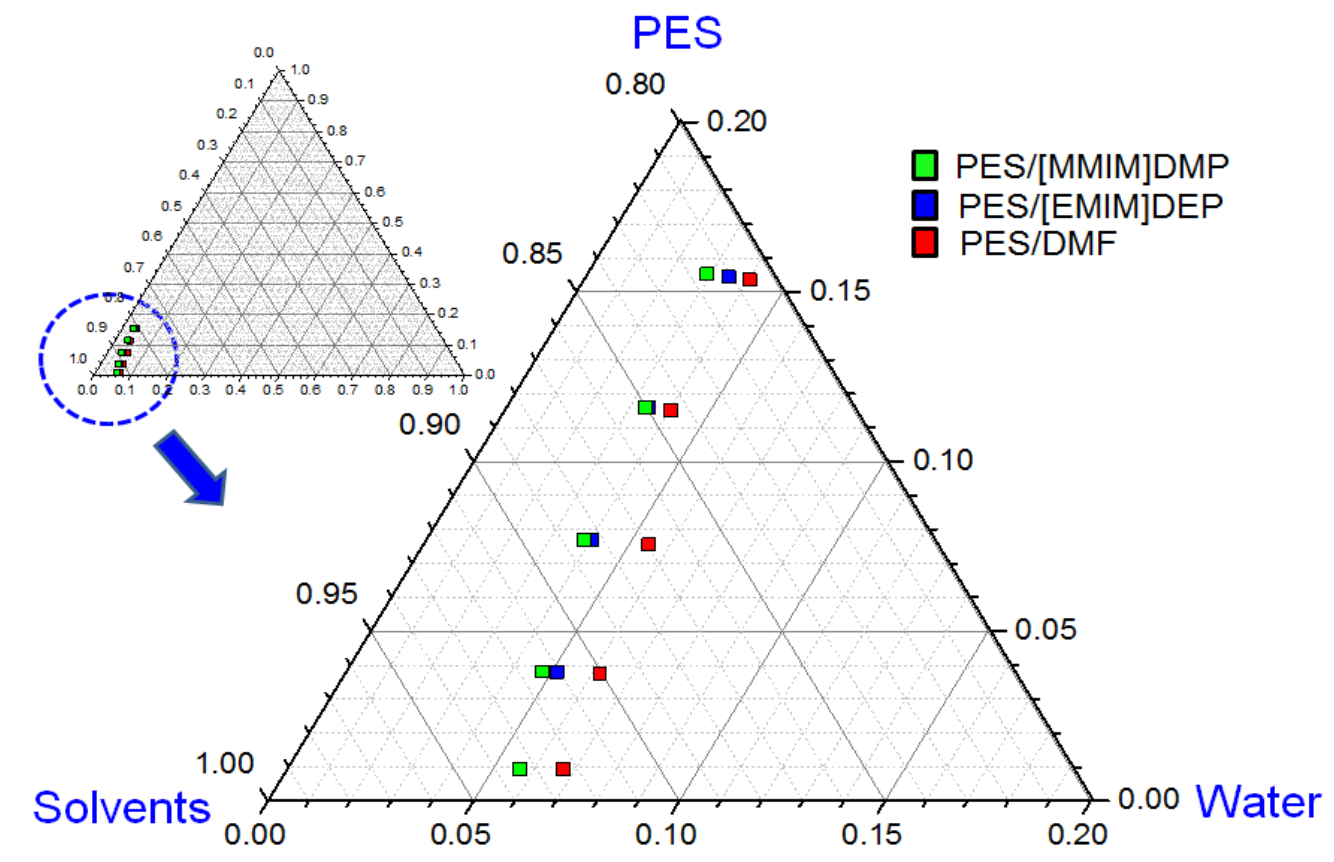

Figure 3. Ternary phase diagram for PES/solvents/water systems

\section{Viscosity}

The aspects discussed above are mainly connected to the thermodynamics of the polymer solutions. Viscosity adds information on kinetics. Viscosity is very important for the fabrication of hollow fibers, to evaluate the feasibility and choose spinning conditions. Viscosity values as a function of temperature are shown in Figure 4. The viscosity of $12 \mathrm{wt} \%$ PES in [EMIM]DEP and [MMIM]DMP is 97 and 60 Pa.s at $25^{\circ} \mathrm{C}$, which is enormous for spinning. By increasing the temperature from 25 to $90{ }^{\circ} \mathrm{C}$, the viscosity dropped down to 4 Pa.s for all polymer solutions, which is up to 25-fold smaller. According to the HagenPoiseuille equation $\left(\mathrm{R}_{\text {hyd }}=8 \eta \mathrm{LQ} / \pi \mathrm{r}^{4}\right)$ [34] in non-ideal fluid dynamics, the hydraulic resistance ( $R_{\text {hyd }}$, the pressure drop) in a tube is proportional to viscosity $(\eta)$. Thus, the hydraulic resistance can be reduced up to 200 times $(8 * 25)$ in tubes connected with spinning machine and the less viscous polymer solution can be spun without the troubles that the high hydraulic resistance could cause.

The viscosity ratio between solution $(\eta)$ and solvent $\left(\eta_{0}\right)$ is shown in Figure $\mathbf{4 b}$ and Table 4. The normalization discounts the pure solvent contribution. At $25^{\circ} \mathrm{C}$ the ratio for 12 wt\% PES decreased in the following order: [MMIM]DMP > [EMIM]DEP > DMF. This is the order of increasing $\mathrm{C}^{*}$ in Table 3. PES in [MMIM]DMP starts to entangle from $\mathrm{C}^{*}$ equal to 
$0.01 \mathrm{~g} / \mathrm{cm}^{3}$ (1 wt $\left.\%\right)$, the lowest value compared to others. $12 \mathrm{wt} \%$ PES solutions in [MMIM]DMP are highly entangled and the viscosity ratio is higher than in other solvents. By increasing temperature, the ratio for all polymer solutions became similarly low.

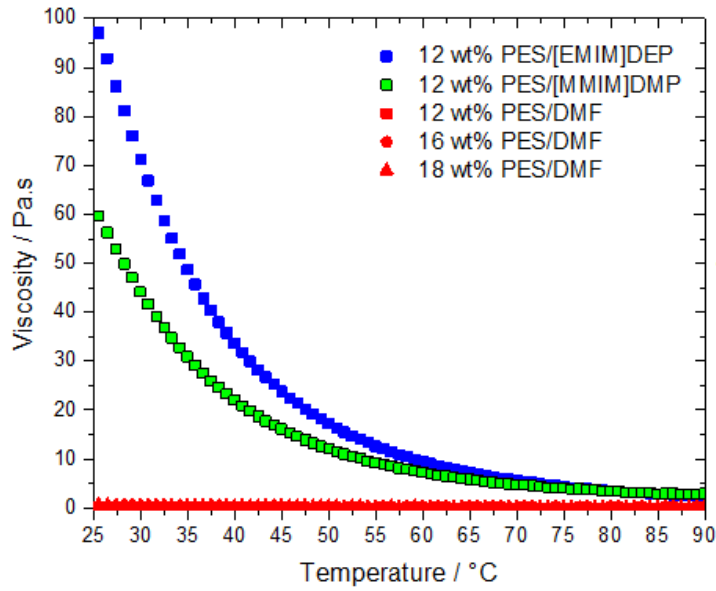

(a)

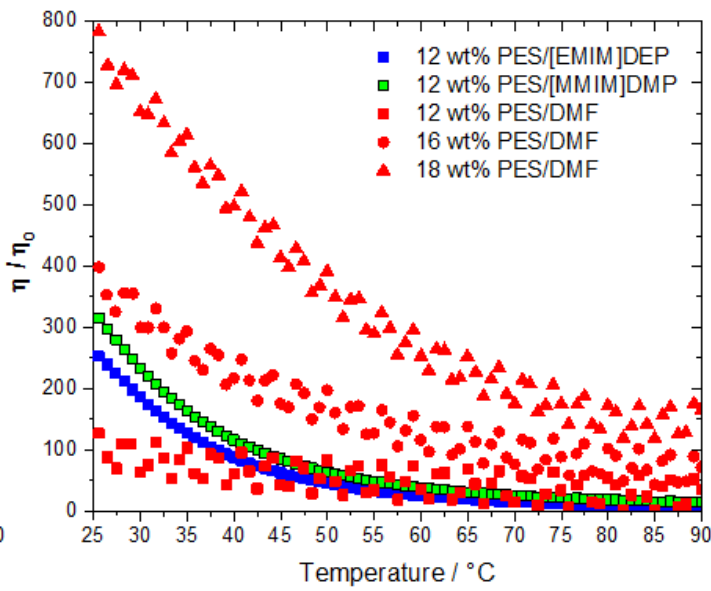

(b)

Figure 4. (a) Viscosity of polymer solutions at different temperatures and (b) ratios between solution and the solvent viscosities.

Table 4. Viscosity of concentrated PES solutions $(\eta)$ and solvents $\left(\eta_{0}\right)$ and their ratios at 25 ${ }^{\circ} \mathrm{C}$.

\begin{tabular}{ccccc}
\hline $\begin{array}{c}\text { PES } \\
\begin{array}{c}\text { concentration } \\
(\text { wt } \%)\end{array}\end{array}$ & Solvents & $\begin{array}{c}\eta \\
(\text { Pa.s })\end{array}$ & $\begin{array}{c}\eta_{0} \\
(\text { Pa.s })\end{array}$ & $\begin{array}{c}\eta / \eta_{0} \\
\text { Ratio }\end{array}$ \\
\hline 12 & [EMIM]DEP & 97.1 & 0.384 & 250 \\
12 & [MMIM]DMP & 59.7 & 0.189 & 320 \\
12 & DMF & 0.1 & 0.00077 & 130 \\
16 & DMF & 0.3 & 0.00077 & 390 \\
18 & DMF & 0.6 & 0.00077 & 780 \\
\hline
\end{tabular}

\subsection{Flat sheet membranes characterization}

Figure 5 shows the morphologies of membranes cast with different solvents. The membranes prepared from $12 \mathrm{wt} \%$ PES in [EMIM]DEP and [MMIM]DMP have homogeneously distributed sponge-like structures with very small pores, which were hardly seen by high magnification of SEM images. On the other hand, the membrane cast from 12 wt \% PES in DMF has finger-like void structure. By increasing the PES concentration in 
DMF from 12 to $18 \mathrm{wt} \%$, the size of finger voids decreased and the membrane thickness increased. The clear difference in structure might be a consequence of different mechanisms of membrane formation.

As we reported in our previous study, the mechanism of nucleation and growth (NG) might predominate during the membrane formation of $12 \mathrm{wt} \% \mathrm{PES} /[\mathrm{EMIM}] \mathrm{DEP}$ and [MMIM]DMP. The higher viscosity favors a slow path into the 2 phases region of the phase diagram, with long time under metastable conditions. Furthermore, once the phase separation starts, the high viscosity contributes for a slow evolution of domain size, before the whole system solidifies to form the final sponge-like pore structure. In opposite the DMF system is characterized by low viscosity. This promotes fast solvent-water exchange and a fast path into the demixing region of the phase diagram delimitated by the spinodal curve. Spinodal decomposition (SD) then predominates. These NG and SD mechanisms explain the formation of the membranes nanopores. Apart from that, the presence or absence of finger-like cavities is defined by other set of considerations: (i) viscosity, (ii) solvent-water mixing Gibbs energy and (iii) homogeneity of the water-polymer solution interface. Abrupt water-solvent exchange favors the formation of finger-like cavities. Solutions in DMF are more prone to that, due to the low viscosity.

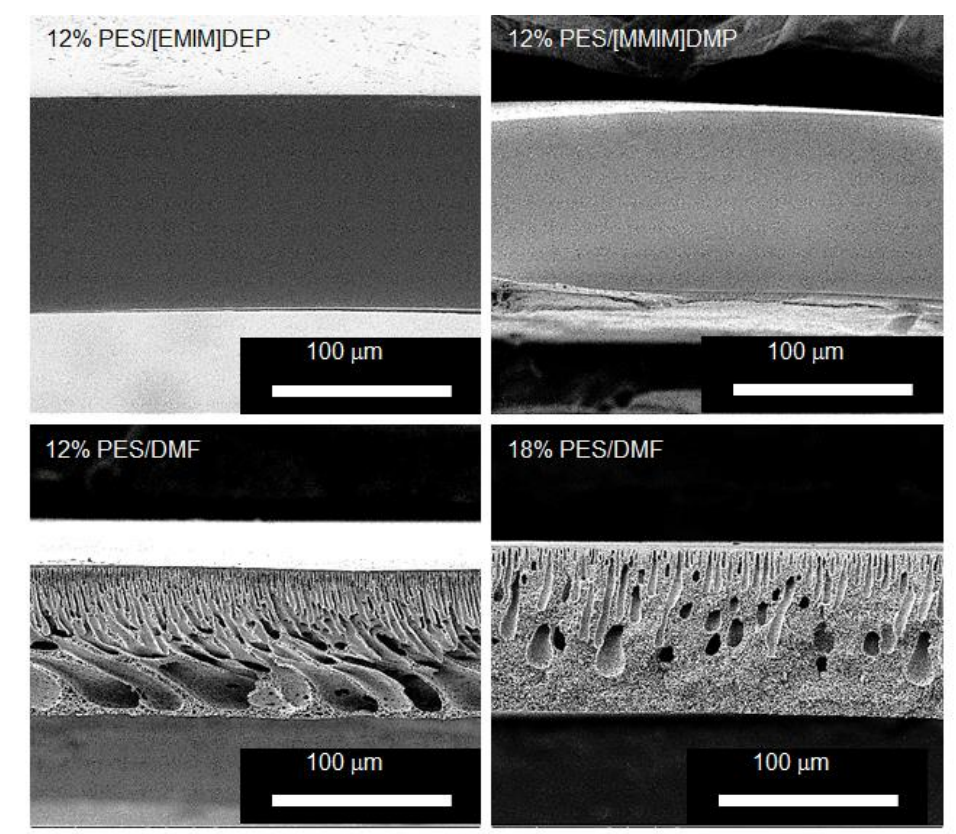

Figure 5. Morphology of PES flat sheet membranes, fabricated from PES solutions in different solvents. 
The performance of flat-sheet membranes prepared from $12 \mathrm{wt} \%$ PES solutions in different solvents is summarized in Table 5 and Figure 6. When [EMIM]DEP and [MMIM]DMP were the used solvents, the membranes water permeances were 55 and $43 \mathrm{Lm}^{-}$ ${ }^{2} \mathrm{~h}^{-1} \mathrm{bar}^{-1}$, respectively. In Figure 6 and Table 5, the pore sizes and their distributions, estimated from PEG rejection tests, are illustrated and summarized. Normally there is a permeance-rejection trade-off. While the water permeance is higher when the membranes are prepared from solutions in DMF, the MWCO is clearly smaller when using [EMIM]DEP and [MMIM]DMP. Figure 6b shows that when using [EMM]DEP, membranes with particularly narrow pore size distribution are obtained, with a mean pore size around $2 \mathrm{~nm}$.

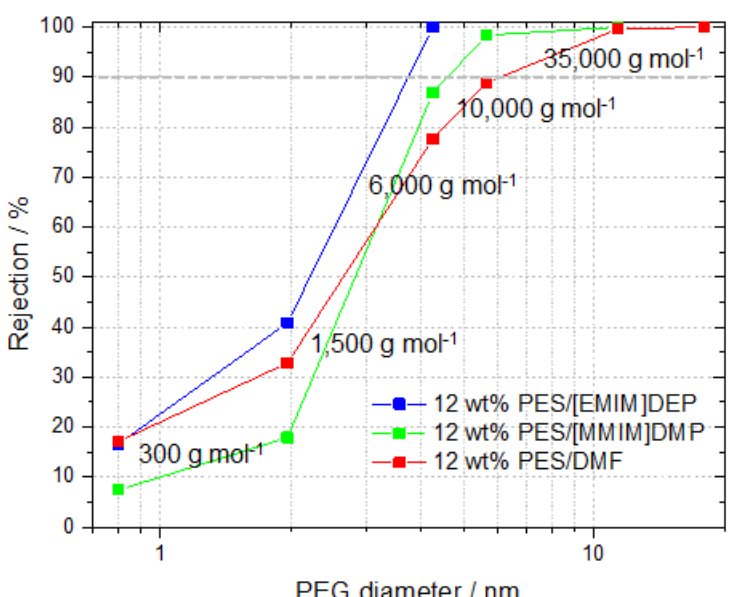

(a)

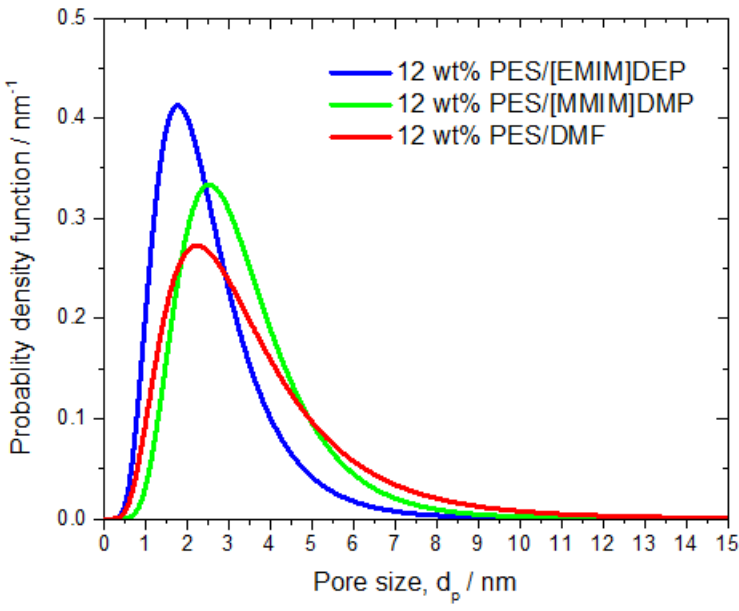

(b)

Figure 6. (a) PEG rejection and (b) pore size distribution of flat sheet membranes. The mixed PEG feed solution was composed of $0.1 \mathrm{wt} \%$ of each of the following molecular weights: 6 , 10,35 , and $100 \mathrm{~kg} \mathrm{~mol}^{-1}$.

Table 5. Performance of flat-sheet membranes prepared from $12 \mathrm{wt} \%$ PES solutions in different solvents; measurements at 2 bar, $25^{\circ} \mathrm{C}$.

\begin{tabular}{cccccccc}
\hline \multirow{2}{*}{$\begin{array}{c}\text { Casting } \\
\text { solvent }\end{array}$} & $\begin{array}{c}\text { Water } \\
\text { permeance } \\
\left(\mathrm{Lm}^{-2} \mathrm{~h}^{-1} \mathrm{bar}^{-1}\right)\end{array}$ & 0.3 & 1.5 & 6 & 10 & 35 & MWCO \\
\cline { 3 - 6 } & & & \multicolumn{5}{c}{ PEG rejection (\%) } \\
[EMIM]DEP & $55 \pm 5$ & 16.7 & 40.9 & 100 & & & 5.1 \\
\hline MMIM]DMP & $43 \pm 3$ & 7.5 & 17.9 & 86.8 & 98.3 & 100 & 7.9 \\
DMF & $135 \pm 5$ & 17.2 & 32.8 & 77.6 & 88.9 & 99.6 & 10.3 \\
\hline
\end{tabular}


After analyzing the PEG rejection results of Table 5, the membranes capability for DNA separation were evaluated. DNA samples with molecular weights of 3153 and $6366 \mathrm{~g}$ $\mathrm{mol}^{-1}$ were used. The results are summarized in Table 6. Flat sheet membranes prepared from $12 \mathrm{wt} \%$ PES/[EMIM]DEP and $12 \mathrm{wt} \%$ PES/[MMIM]DMP solutions rejected respectively 99 and $92 \%$ of DNA with $3153 \mathrm{~g} \mathrm{~mol}^{-1}$ molecular weight, indicating that the rejection curves are even sharper than characterized by PEG measurements (Figure 8a). The membranes prepared from solutions in DMF with the same polymer concentration rejected only $7 \%$, a values lower than obtained with PEG measurements, using PEG mixtures. $100 \%$ DNA with $6366 \mathrm{~g} \mathrm{~mol}^{-1}$ molecular weight was removed by membranes prepared from solutions in ionic liquids. The membrane separation of charged solutes, like DNA, could be affected by size exclusion and Donnan exclusion. This is clearly seen for PES/[EMIM]DEP membranes, which have pores in the range of tight ultrafiltration and loose nanofiltration, separating DNA with molecular weights 5.7 and $7.9 \mathrm{~kg} \mathrm{~mol}^{-1}$. PEG is neutral and Donnan exclusion is not relevant for the separation.

Table 6. DNA separation by flat sheet membranes.

\begin{tabular}{lcc}
\hline & \multicolumn{2}{c}{ Rejection (\%) } \\
\cline { 2 - 3 } & DNA & DNA \\
& $\left(\mathrm{M}_{\mathrm{w}}=3153 \mathrm{~g} \mathrm{~mol}^{-1}\right)$ & $\left(\mathrm{M}_{\mathrm{w}}=6366 \mathrm{~g} \mathrm{~mol}^{-1}\right)$ \\
\hline $12 \mathrm{wt} \%$ PES/[EMIM]DEP & 98.8 & 100 \\
$12 \mathrm{wt} \%$ PES/[MMIM]DMP & 92.2 & 100 \\
$12 \mathrm{wt} \%$ PES/DMF & 7.0 & 27.2 \\
\hline
\end{tabular}

When comparing only membranes prepared by the two ionic liquids, [EMIM]DEP and [MMIM]DMP, thermodynamic and kinetic aspects have to be considered. From the thermodynamic point of view the two systems are similar, with small differences in the DFT calculations. The membrane morphologies are also highly influenced by the phase separation kinetics, and for that viscosity is an important factor. As shown in Figure 4, the viscosity of PES/[EMIM]DEP is $100 \mathrm{~Pa} . \mathrm{s}$, which is about 970 times higher than that of PES/DMF. The viscosity of PES/[MMIM]DMP is approximately 600 times higher than that of PES/DMF, still much lower than that of PES/[EMIM]DEP. Both membranes have sponge-like structure with fine and well-connected pores. However, because of the high viscosity, PES/[EMIM]DEP has less mobility, the evolution of the phase separation is slower, the pores are smaller (lower MWCO) and the pore distribution narrower, as shown in Figure 6b. The difference of water permeance between the two membranes was less pronounced. 


\subsection{Hollow fiber membranes}

After demonstrating the feasibility and the performance of flat-sheet membranes prepared from solutions in ionic liquids, hollow fibers were manufactured. PES/[EMIM]DEP was chosen because of the combination of low MWCO and high flux, demonstrated as flatsheet. Hollow fiber manufacture is more sensitive to viscosity than flat-sheet. $12 \mathrm{wt} \%$ PES/[EMIM]DEP solutions led to well-formed hollow fibers, after optimization of spinning conditions, as shown in Table 7. For hollow fibers only one ionic liquid was used: [EMIM]DEP. They are referred as PES/IL, followed by values of air gap difference and dope temperature. The viscosity of $12 \mathrm{wt} \%$ PES/DMF solutions is too low for hollow fiber manufacture. Attempts led to deformed fibers. $18 \mathrm{wt} \%$ PES/DMF could be spun to fabricate hollow fiber membranes, which were compared to those prepared from solutions in [EMIM]DEP.

The morphologies of all fabricated hollow fiber membranes are depicted in Figure 7. Similarly to results for flat sheet membranes, [EMIM]DEP and DMF lead to membrane structures and pore sizes, which are clearly different. 18PES/DMF-2/25 in Figure 7 had double layered finger-like voids in outer and inner surfaces. The double layers are formed because the polymer solutions contact water as a strong non-solvent from both sides; the inner surface from the bore fluid and the outer surface from the coagulant water. Similar to flat-sheet membranes finger-like structures are formed with DMF. In contrast all hollow fibers prepared from solutions in [EMIM]DEP had the spongy-like structures with fine pores and a small number of voids.

By increasing the air-gap and the temperature of the dope solution, the thickness of hollow fiber membranes was decreased as depicted in Figure 7 and Figure 8. By changing the air-gap, which are the distance from the extrusion point to the air to the surface of nonsolvent, from 2 (12PES/IL-2/70) to $5 \mathrm{~cm}$ (12PES/IL-5/70), the thickness of the hollow fibers was reduced from 276 to $245 \mu \mathrm{m}$ and when the gap increased from 5 (12PES/IL-5/90) to 30 cm (12PES/IL-30/90), the thickness decreased from 232 to $165 \mu \mathrm{m}$ due to spun stretching by gravity. Furthermore, the effect of the dope solution temperature on membrane thickness could be seen, by comparing 12PES/IL-5/70 and 12PES/IL-5/90. As a consequence of decreasing the viscosity of the dope solutions, by increasing the temperature, the spun dope solution becomes thinner and flexible, with stretching by gravity being more accentuated. Similar results were obtained for membranes prepared from 18PES/DMF (Figure 8). 

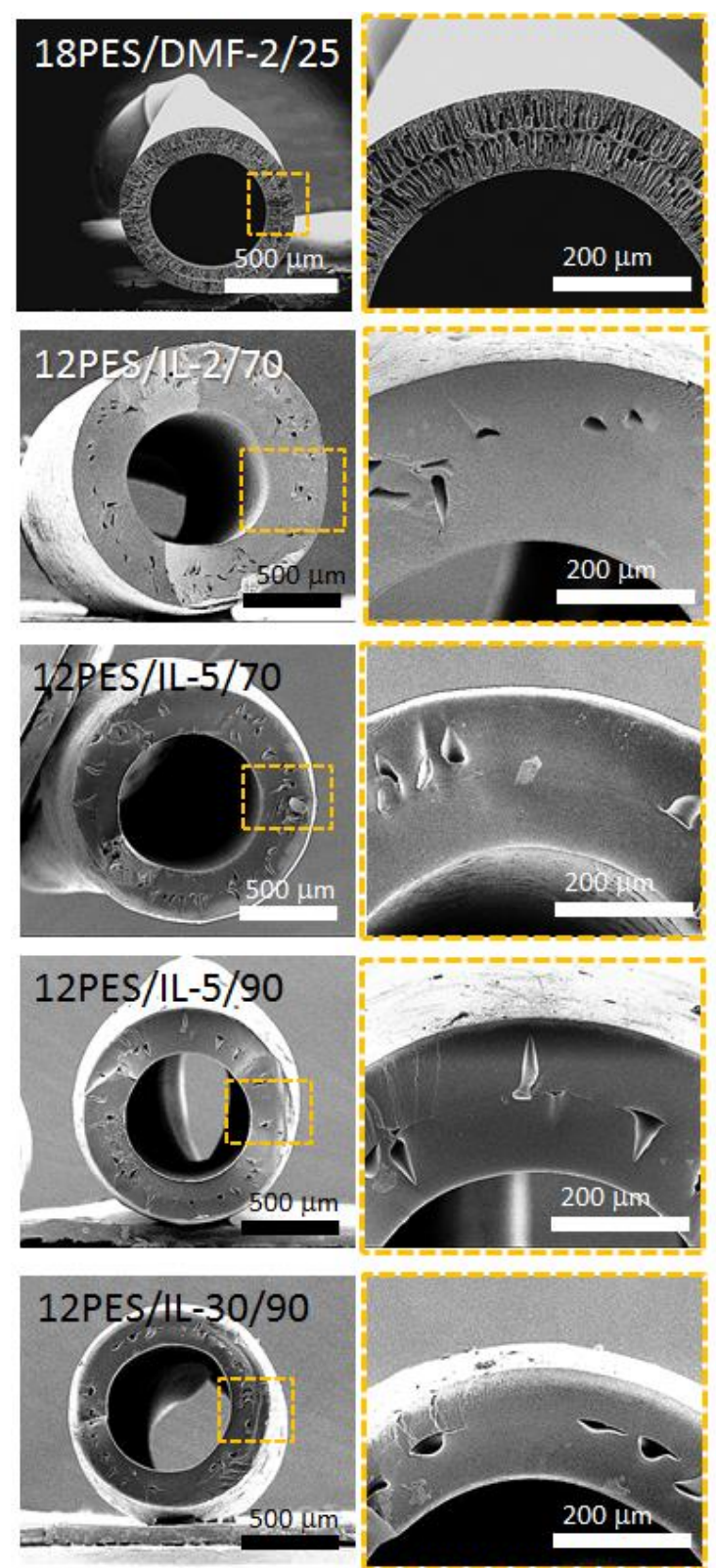

Figure 7. Morphology of manufactured hollow fiber membranes.

Table 7. Summary of hollow fiber preparation conditions and resulting dimensions.

\begin{tabular}{cccccc}
\hline Hollow fibers & $\begin{array}{c}\text { 18PES/DMF- } \\
2 / 25\end{array}$ & $\begin{array}{c}\text { 12PES/IL- } \\
2 / 70\end{array}$ & $\begin{array}{c}\text { 12PES/IL- } \\
5 / 70\end{array}$ & $\begin{array}{c}\text { 12PES/IL- } \\
5 / 90\end{array}$ & $\begin{array}{c}\text { 12PES/IL- } \\
30 / 90\end{array}$ \\
\hline Dope solutions & $\begin{array}{c}18 \mathrm{wt} \% \\
\text { PES/DMF }\end{array}$ & & $12 \mathrm{wt} \%$ PES/[EMIM]DEP & \\
\hline Air gap $(\mathrm{cm})$ & 2 & 2 & 5 & 5 & 30 \\
\hline $\begin{array}{c}\text { Temperature of dope } \\
\text { solutions }\left({ }^{\circ} \mathrm{C}\right)\end{array}$ & 25 & 70 & 70 & 90 & 90 \\
\hline $\begin{array}{c}\text { Outer diameter }(\mu \mathrm{m}) \\
\text { Wall thickness }(\mu \mathrm{m})\end{array}$ & 770 & 1300 & 1117 & 1060 & 985 \\
\hline
\end{tabular}


The pure water permeance of all hollow fiber membranes is summarized in Table 8 . The permeance of hollow fiber membranes prepared from 18PES/DMF-2/25 solutions was higher than that of those prepared from 12PES in [EMIM]DEP. By decreasing the wall thickness from $276 \mu \mathrm{m}(12 \mathrm{PES} / \mathrm{IL}-2 / 70)$ to $165 \mu \mathrm{m}$ (12PES/IL-30/90) in Table 7, the pure water permeance was increased from 22.4 to $45.8 \mathrm{Lm}^{-2} \mathrm{~h}^{-1} \mathrm{bar}^{-1}$. The higher porosity, resulted from the bigger pore size and the finger-like voids, and the thinner wall thickness of 18PES/DMF2/25 may have an effect on the high water permeance. However, the PEG rejection of all hollow fibers prepared in [EMIM]DEP was higher than that prepared from 18PES/DMF-2/25, as shown in Figure 9 and Table 8. MWCOs of fibers prepared from 12PES in [EMIM]DEP and 18PES/DMF were 1.4 and $10.5 \mathrm{~kg} \mathrm{~mol}^{-1}$, respectively, using a mixture of PEG molecular weights. As far as pore distribution is concerned, as shown in Figure 9, a broad distribution was measured for 18PES/DMF-2/25, while those for all fibers prepared from 12PES/[EMIM[DEP solutions was very narrow. Overall, the PEG rejection and the pore distribution were respectively higher and narrow once higher polymer concentration was used for membrane preparation.

We had two different procedures for PEG rejection tests: (i) using a mixture of molecular weights at once or (ii) measuring separately the rejection of single molecular weights one by one. The results were slightly different, as shown in Table 8. The rejection values were higher, when measured with the PEG mixture. The difference was even more significant for 18PES/DMF than for those membranes prepared from solutions in [EMIM]DEP. This can be probably explained by considering the formation of a cake layer of larger PEG molecules, deposited on the membrane surface when tested in dead-end cells. The membrane fabricated from the PES/DMF polymer solution has very broad pore size distribution. When the PEG mixture is used for rejection measurements, the high molecular weight PEG fraction might form a gel layer or cake, partially filling the larger pores and masquerading the results. The rejection is therefore apparently higher than when single samples of defined molecular weight are used. Membranes prepared from solutions in [EMIM]DEP have narrow pore size distribution, with smaller average size. The rejections are higher for all solutes. The variations in results with single and mixture of PEGs are less pronounced and only detectable for low molecular weight. 

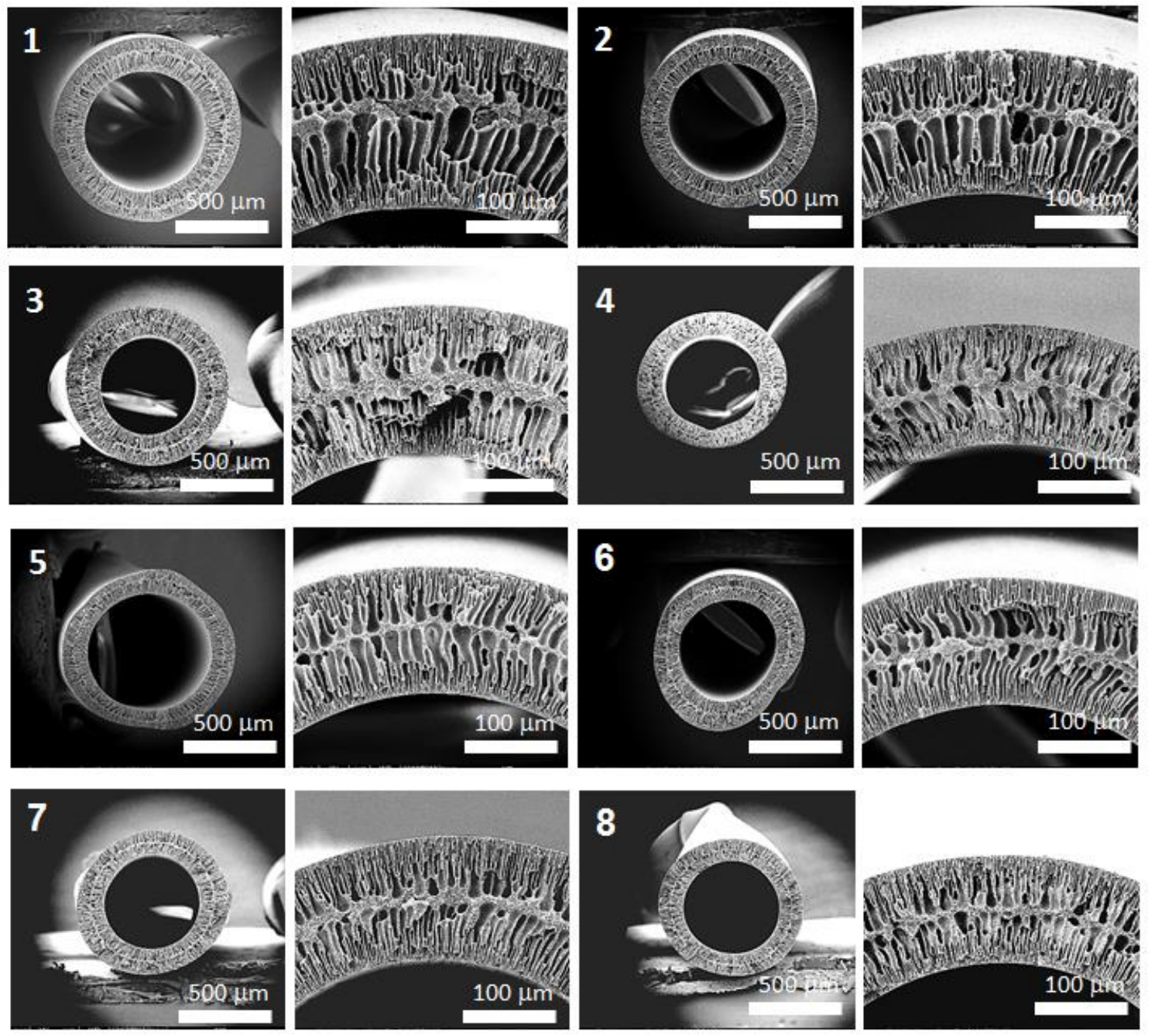

\begin{tabular}{ccccccccc}
\hline Sample No. & 1 & 2 & 3 & 4 & 5 & 6 & 7 & 8 \\
\hline Outer diameter $(\mu \mathrm{m})$ & 1010 & 930 & 950 & 870 & 780 & 900 & 850 & 770 \\
Wall thickness $(\mu \mathrm{m})$ & 190 & 210 & 155 & 165 & 130 & 140 & 140 & 119 \\
\hline
\end{tabular}

Figure 8. Morphologies of the hollow fiber membranes spun from $18 \mathrm{wt} \%$ PES/DMF solutions. 

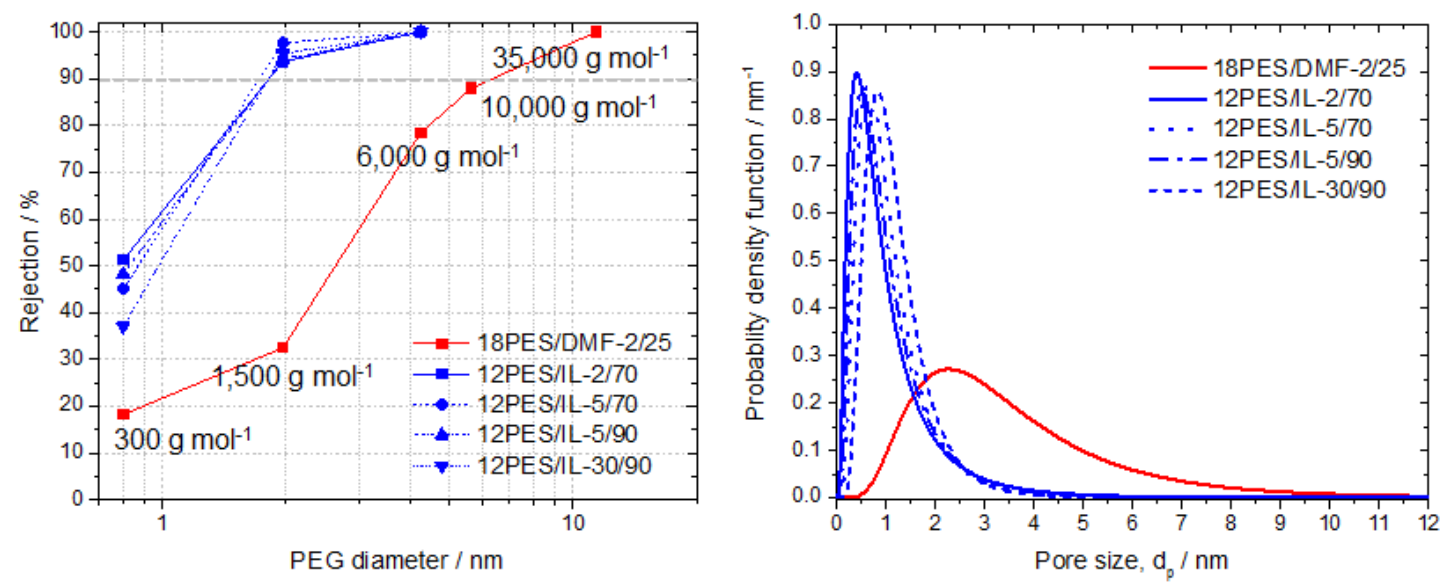

Figure 9. PEG rejection and the pore distribution of tested hollow fiber membranes.

Table 8. Summary of pure water permeance and PEG rejection for hollow fiber membranes; experiments with feeds containing a mixture of PEG molecular weights or single PEG molecular weights.

\begin{tabular}{|c|c|c|c|c|c|c|c|c|}
\hline \multirow{2}{*}{ Hollow fibers } & \multirow{2}{*}{$\begin{array}{c}\text { Water } \\
\text { permeance } \\
\left(\mathrm{Lm}^{-2} \mathrm{~h}^{-1} \mathrm{bar}^{-1}\right)\end{array}$} & \multicolumn{6}{|c|}{ PEG rejection (\%) (PEG mixture / single PEG) } & \multirow{2}{*}{$\begin{array}{l}\mathrm{MWCO} \\
\left(\mathrm{kg} \mathrm{mol}^{-1}\right)\end{array}$} \\
\hline & & 0.3 & 1.5 & 3 & 6 & 10 & 35 & \\
\hline $\begin{array}{c}\text { 18PES/DMF- } \\
2 / 25\end{array}$ & 87.6 & $18 /-$ & $33 /-$ & -17 & 79 / 14 & $\begin{array}{c}88 / \\
-\end{array}$ & $\begin{array}{c}100 / \\
-\end{array}$ & $11 / 37$ \\
\hline $\begin{array}{c}\text { 12PES/IL- } \\
2 / 70\end{array}$ & 22.4 & $51 /-$ & $94 / 72$ & - / 89 & $100 / 96$ & & & $1.4 / 3.5$ \\
\hline $\begin{array}{c}\text { 12PES/IL- } \\
5 / 70\end{array}$ & 17.8 & $45 /$ - & $98 / 82$ & - / 94 & $100 / 96$ & & & $1.3 / 2.5$ \\
\hline $\begin{array}{l}\text { 12PES/IL- } \\
5 / 90\end{array}$ & 25.9 & $48 /-$ & $94 / 77$ & $-/ 87$ & $100 / 96$ & & & $1.4 / 3.9$ \\
\hline $\begin{array}{c}\text { 12PES/IL- } \\
30 / 90\end{array}$ & 45.8 & $37 /-$ & $95 / 11$ & $-/ 34$ & $100 / 97$ & & & $1.4 / 5.7$ \\
\hline
\end{tabular}

Table 9 shows the mechanical properties for flat-sheet and hollow fiber membranes. Overall, the membranes have values of tensile strength at break in the same order of magnitude. Slight differences can be observed. The values of elongation at break for membranes fabricated from PES/DMF were higher than for those fabricated from PES/ionic liquids, but in all cases the membranes were strong enough for testing and for further application. 
Table 9. Membrane mechanical properties.

\begin{tabular}{|c|c|c|c|c|}
\hline & \multirow[b]{2}{*}{ PES solutions } & \multicolumn{2}{|c|}{ Mechanical strength } & \multirow[b]{2}{*}{$\begin{array}{l}\text { Young's } \\
\text { modulus } \\
(\mathrm{MPa})\end{array}$} \\
\hline & & $\begin{array}{c}\text { Tensile strength } \\
\text { at break } \\
(\mathrm{MPa})\end{array}$ & $\begin{array}{c}\text { Elongation } \\
\text { at break } \\
(\%)\end{array}$ & \\
\hline \multirow{4}{*}{$\begin{array}{l}\text { Flat } \\
\text { sheet }\end{array}$} & 12 wt\% PES/[EMIM]DEP & $2.2 \pm 0.2$ & $18 \pm 1$ & 0.4 \\
\hline & 12 wt\% PES/[MMIM]DMP & $1.8 \pm 0.3$ & $13 \pm 2$ & 0.2 \\
\hline & $12 \mathrm{wt} \% \mathrm{PES} / \mathrm{DMF}$ & $3.5 \pm 0.3$ & $65 \pm 18$ & 0.8 \\
\hline & $18 \mathrm{wt} \% \mathrm{PES} / \mathrm{DMF}$ & $7.0 \pm 0.5$ & $131 \pm 60$ & 1.5 \\
\hline \multirow{5}{*}{$\begin{array}{l}\text { Hollow } \\
\text { fiber }\end{array}$} & 18PES/DMF-2/25 & $6.0 \pm 1.3$ & $84 \pm 56$ & 1.4 \\
\hline & 12PES/IL-2/70 & $2.3 \pm 0.3$ & $40 \pm 29$ & 0.3 \\
\hline & 12PES/IL-5/70 & $3.0 \pm 0.1$ & $46 \pm 6$ & 0.3 \\
\hline & 12PES/IL-5/90 & $4.0 \pm 0.3$ & $51 \pm 12$ & 0.5 \\
\hline & 12PES/IL-30/90 & $2.8 \pm 0.1$ & $25 \pm 5$ & 0.4 \\
\hline
\end{tabular}

\section{CONCLUSION}

We have theoretically and experimentally studied the interaction and solubility of PES and PSf in ionic liquids. We fabricated flat sheet and hollow fiber membranes from PES solutions in [MMIM]DMP and [EMIM]DEP. The following conclusions can be taken:

(1) Evaluation of the interaction energy of PES and PSf with ionic liquids, using DFT, shows that the electrostatic contribution is higher for PES than for PSf, which can explain that only PES is soluble.

(2) The polymer coil size of the diluted PES solution in different solvents was calculated by the intrinsic viscosity and was measured by DLS. The order of the PES coil size was PES/[MMIM]DMP $\geq \mathrm{PES} /[\mathrm{EMIM}] \mathrm{DEP} \geq \mathrm{PES} / \mathrm{DMF}$. It is consistent with the results of DFT calculation. From the thermodynamic point of view, the ionic liquids, [MMIM]DMP and [EMIM]DEP, are better solvents for PES than DMF. 
(3) The polymer solutions in [MMIM]DMP and [EMIM]DEP were highly viscous. Much lower viscosity was measured in DMF.

(4) Flat-sheet and hollow fiber membranes were fabricated. The membrane prepared from 12 wt \% PES in [EMIM]DEP and [MMIM]DMP had sponge-like structures with small pores. On the other hand, the membrane cast from $12 \mathrm{wt} \%$ PES in DMF had finger-like structures.

(5) The membranes fabricated from 12 wt \% PES in [EMIM]DEP and [MMIM]DMP had lower pure water permeance but higher PEG rejection and narrower pore size distribution than those prepared from $12 \mathrm{wt} \%$ PES solution in DMF.

(6) 99 and $92 \%$ of DNA with $3153 \mathrm{~g} \mathrm{~mol}^{-1}$ were rejected by the membranes prepared from $12 \mathrm{wt} \%$ PES/[EMIM]DEP and $12 \mathrm{wt} \%$ PES/[MMIM]DMP, respectively. DNA with $6366 \mathrm{~g} \mathrm{~mol}^{-1}$ was completely removed by membranes prepared from solutions in ionic liquids.

\section{ACKNOWLEDGEMENTS}

The research reported in this publication was supported by funding from King Abdullah University of Science and Technology (KAUST).

\section{REFERENCES}

[1] M. Ulbricht, O. Schuster, W. Ansorge, M. Ruetering, P. Steiger, Influence of the strongly anisotropic cross-section morphology of a novel polyethersulfone microfiltration membrane on filtration performance, Separation and Purification Technology, 57 (2007) 63-73.

[2] K.-V. Peinemann, S.P. Nunes, Membrane Technology, Volume 1: Membranes for Life Sciences, John Wiley \& Sons, 2011.

[3] J.L. Tambosi, R.F. de Sena, M. Favier, W. Gebhardt, H.J. José, H.F. Schröder, R.d.F.P.M. Moreira, Removal of pharmaceutical compounds in membrane bioreactors (MBR) applying submerged membranes, Desalination, 261 (2010) 148-156.

[4] K.-V. Peinemann, S.P. Nunes, L. Giorno, Membrane Technology, Volume 3: Membranes for Food Applications, John Wiley \& Sons, 2011.

[5] C. Regula, E. Carretier, Y. Wyart, G. Gésan-Guiziou, A. Vincent, D. Boudot, P. Moulin, Chemical cleaning/disinfection and ageing of organic UF membranes: A review, Water Research, 56 (2014) 325-365.

[6] M.A. Shannon, P.W. Bohn, M. Elimelech, J.G. Georgiadis, B.J. Mariñas, A.M. Mayes, Science and technology for water purification in the coming decades, Nature, 452 (2008) 301-310.

[7] N.L. Le, S.P. Nunes, Materials and membrane technologies for water and energy sustainability, Sustainable Materials and Technologies, 7 (2016) 1-28.

[8] The European Chemicals Agency.

[9] A. Figoli, T. Marino, S. Simone, E. Di Nicolo, X.M. Li, T. He, S. Tornaghi, E. Drioli, Towards non-toxic solvents for membrane preparation: a review, Green Chemistry, 16 (2014) 4034-4059.

[10] R.D. Rogers, K.R. Seddon, Ionic Liquids--Solvents of the Future?, Science, 302 (2003) 792-793.

[11] I. Ali Mohammad, Green Solvents I: Properties and Applications in Chemistry, (2012). 
[12] M. Freemantle, DESIGNER SOLVENTS, Chemical \& Engineering News Archive, 76 (1998) 32-37.

[13] J.S. Moulthrop, R.P. Swatloski, G. Moyna, R.D. Rogers, High-resolution 13C NMR studies of cellulose and cellulose oligomers in ionic liquid solutions, Chemical Communications, (2005) 15571559 .

[14] R.P. Swatloski, S.K. Spear, J.D. Holbrey, R.D. Rogers, Dissolution of Cellose with Ionic Liquids, Journal of the American Chemical Society, 124 (2002) 4974-4975.

[15] N. Sun, M. Rahman, Y. Qin, M.L. Maxim, H. Rodriguez, R.D. Rogers, Complete dissolution and partial delignification of wood in the ionic liquid 1-ethyl-3-methylimidazolium acetate, Green Chemistry, 11 (2009) 646-655.

[16] S. Zhu, Y. Wu, Q. Chen, Z. Yu, C. Wang, S. Jin, Y. Ding, G. Wu, Dissolution of cellulose with ionic liquids and its application: a mini-review, Green Chemistry, 8 (2006) 325-327.

[17] D.Y. Xing, S.Y. Chan, T.-S. Chung, Molecular interactions between polybenzimidazole and [EMIM]OAc, and derived ultrafiltration membranes for protein separation, Green Chemistry, 14 (2012) 1405-1412.

[18] D. Kim, N.L. Le, S.P. Nunes, The effects of a co-solvent on fabrication of cellulose acetate membranes from solutions in 1-ethyl-3-methylimidazolium acetate, Journal of Membrane Science, 520 (2016) 540-549.

[19] S. Livazovic, Z. Li, A.R. Behzad, K.V. Peinemann, S.P. Nunes, Cellulose multilayer membranes manufacture with ionic liquid, Journal of Membrane Science, 490 (2015) 282-293.

[20] D. Kim, N. Moreno, S.P. Nunes, Fabrication of polyacrylonitrile hollow fiber membranes from ionic liquid solutions, Polymer Chemistry, 7 (2016) 113-124.

[21] D.Y. Xing, N. Peng, T.-S. Chung, Investigation of unique interactions between cellulose acetate and ionic liquid [EMIM]SCN, and their influences on hollow fiber ultrafiltration membranes, Journal of Membrane Science, 380 (2011) 87-97.

[22] D.Y. Xing, N. Peng, T.-S. Chung, Formation of Cellulose Acetate Membranes via Phase Inversion Using Ionic Liquid, [BMIM]SCN, As the Solvent, Industrial \& Engineering Chemistry Research, 49 (2010) 8761-8769.

[23] D. Kim, O.R. Salazar, S.P. Nunes, Membrane manufacture for peptide separation, Green Chemistry, (2016).

[24] S.P. Nunes, K.V. Peinemann, Membrane Preparation, in: Membrane Technology, Wiley-VCH Verlag GmbH \& Co. KGaA, 2006, pp. 9-14.

[25] M. Frisch, G. Trucks, H. Schlegel, G. Scuseria, M. Robb, J. Cheeseman, G. Scalmani, V. Barone, B. Mennucci, G. Petersson, Gaussian 09, revision D. 01, in, Gaussian, Inc., Wallingford CT, 2009. [26] Y. Zhao, D.G. Truhlar, The M06 suite of density functionals for main group thermochemistry, thermochemical kinetics, noncovalent interactions, excited states, and transition elements: two new functionals and systematic testing of four M06-class functionals and 12 other functionals, Theoretical Chemistry Accounts, 120 (2008) 215-241.

[27] J.M. Turney, A.C. Simmonett, R.M. Parrish, E.G. Hohenstein, F.A. Evangelista, J.T. Fermann, B.J. Mintz, L.A. Burns, J.J. Wilke, M.L. Abrams, N.J. Russ, M.L. Leininger, C.L. Janssen, E.T. Seidl, W.D. Allen, H.F. Schaefer, R.A. King, E.F. Valeev, C.D. Sherrill, T.D. Crawford, Psi4: an opensource ab initio electronic structure program, Wiley Interdisciplinary Reviews: Computational Molecular Science, 2 (2012) 556-565.

[28] A. Dondos, C. Tsitsilianis, Viscometric study of extremely dilute macromolecular solutions: Critical concentration $\mathrm{c}$ and the intrinsic viscosity of the polystyrene through scaling laws. The values of the Huggins constant, Polymer International, 28 (1992) 151-156.

[29] S. Singh, K. Khulbe, T. Matsuura, P. Ramamurthy, Membrane characterization by solute transport and atomic force microscopy, Journal of Membrane Science, 142 (1998) 111-127. [30] A. Rahimpour, S.S. Madaeni, Y. Mansourpanah, Nano-porous polyethersulfone (PES) membranes modified by acrylic acid (AA) and 2-hydroxyethylmethacrylate (HEMA) as additives in the gelation media, Journal of Membrane Science, 364 (2010) 380-388.

[31] S. Singh, K.C. Khulbe, T. Matsuura, P. Ramamurthy, Membrane characterization by solute transport and atomic force microscopy, Journal of Membrane Science, 142 (1998) 111-127. 
[32] Q.T. Nguyen, J. Neel, Characterization of ultrafiltration membranes. : Part IV. Influence of the deformation of macromolecular solutes on the transport through ultrafiltration membranes, Journal of Membrane Science, 14 (1983) 111-127.

[33] L. Shen, L. Li, J. Chen, H. Hong, H. Yu, Z. Hou, H. Lin, X. Lu, Effects of molecular weight distribution (Md) on the performances of the polyethersulfone (PES) ultrafiltration membranes, Journal of Membrane Science, 490 (2015) 220-226.

[34] H. Bruus, Theoretical Microfluidics, OUP Oxford, 2008. 